\title{
‘The magical operations of separation': English elite schools' on-line geographies, internationalisation and functional isolation
}

\begin{abstract}
This paper examines the enduring separation and isolation of elite schools in England, in the face of increasing and substantial internationalisation. It presents the findings of a research project examining the geographical narratives produced by 30 elite schools on their websites and through their prospectuses, newsletters, blogs and twitter feeds. A critical visual and textual analysis was undertaken. Drawing on these data, the paper argues that elite schools remain highly focused on promoting and defending their separateness and isolation, despite extensive, documented international involvements. Work on institutional and carceral geographies and geographies of education have provided some theoretical justification for why this might be the case, and we explore these reasons here. The paper concludes with a plea for more work on the elite schooling sector in England, as their spatial practices (isolation and internationalisation) continue to have a weighty bearing upon society.
\end{abstract}

Keywords: elite education; internationalisation; functional isolation; geographies of education; carceral geographies 


\subsection{Introduction}

'A total institution may be defined as a place of residence and work where a large number of like-situated individuals, cut off from the wider society for an appreciable period of time, together lead an enclosed, formally administered round of life' (Goffman, 1961, p.11).

It is generally acknowledged - if not openly celebrated - that elite public schools in England operate a putative policy of 'functional isolation'. . All of the Sutton Trust's (2012) 'most influential' private schools offer boarding to pupils during term time (taken up by the majority of young people attending these institutions). Harrow School (for boys), for example, describes, on its website, why someone new to the school should consider boarding:

'If you are currently at a day school, you may wish to experience the excitement and activity of boarding life. A boarding school gives you masses of time to do sport, music, and all the other activities you might wish you could do now but which aren't available at your current school. It also creates bonds between pupils that are often stronger than the friendships created at day schools because you are with your friends all the time during term-time. You will learn to live independently and to co-exist with other individuals in a way that gives excellent training for life at university and in the work place'.

\footnotetext{
${ }^{1}$ We use the term 'functional isolation' in this paper to stress the practical functionality of schools' attempts to isolate and segregate their pupils.
} 
This statement provides some insight into the functions that isolation serve within the boarding school environment. What is less apparent from this quote, however, and from a broader glance at the websites of elite private schools in England, is the extent of internationalisation (for want of a better term) that is occurring here. Public schools have always had a substantial body of pupils from overseas, who have been drawn to this school sector precisely because of its quirky yet undeniably advantageous otherness, developed through a sense of isolation. However, as our research has shown, in recent years the internationalisation of elite English schools has reached new depths, and has expanded in hitherto unseen ways. Many examples of this can be found, and we will discuss some of these in this paper. Perhaps the most striking, however, is the unprecedented emergence of overseas satellite campuses; a total of 39 UK independent schools now have branches abroad, located mainly in East and Southeast Asia (ISC, 2014). And yet we understand very little, at the present time, about the socio-spatial implications of this phenomenon. A very different but still notable example of internationalisation is seen reflected in the increasing number of pupils attending private and elite state schools applying to, and securing places at, universities overseas for undergraduate studies (Paton, 2013). For example, in 2012, $9 \%$ of one school's sixth-form leavers went overseas to universities in Europe or North America. At another school in 2011, 29 sixth-form pupils secured a place at an overseas university. Although these figures are relatively small, they signal a growing trend in UK pupils applying to institutions abroad for first-degree places $^{2}$ (Authors, 2011). As we will demonstrate below, according to several different measures, elite schools in England are significantly engaging in internationalisation, and yet are largely avoiding overtly displaying this fact (Authors, 2014).

\footnotetext{
${ }^{2}$ Study abroad has always been popular at graduate (Masters and $\mathrm{PhD}$ ) level, but this increase at undergraduate level is a relatively new phenomenon.
} 
The enduring tendency to foreground isolation and insularity above international connectedness is surprising, also, in the context of other research that has shown how schools use their 'international credentials' in order to distinguish themselves from others in a crowded and competitive education market. A recent presentation at the RGS-IBG annual international conference by Campbell-Price and Duncan (2014) argued that schools in New Zealand are extremely keen to showcase international school trips on marketing materials and at open days. Similarly, in the context of Brazil, Aguiar and Nogueira (2012) have shown that private schools are explicitly foregrounding an 'international strategy' in promotional materials. Thus, in other contexts it would seem, internationalisation is something to be flaunted, not hidden.

This paper juxtaposes the evidence we found of elite English schools' internationalisation with their owndepictions of isolation and narratives of separation. We then attempt to understand this standpoint, drawing upon literature from 'institutional geographies' (Philo and Parr 2000) and 'carceral geographies' (Moran, 2013), to explore, conceptually, the meanings of isolation in this empirical context. One modest aim is simply to ask whether any useful linkages between these areas of study (incarceration and schooling) can in fact be drawn (in the manner of Goffman, 1961). We also take inspiration from research in the sociology of education (on social and cultural capital) and geographies of education (on informal and alternative learning) to help elucidate the significance of elite schools' contemporary spatial practices.

The paper presents the findings of a recent research project, which has considered the geographies of elite schooling in England. Specifically, we have undertaken an in-depth examination of different, publicly available texts produced by 30 elite schools (websites, prospectuses, newsletters, twitter feeds and blogs) to gauge the geographies that they present to an external audience. In this paper, the argument will proceed as follows: first, we consider 
literature that has (in different contexts) examined the concept of isolation and institutions. We begin with a discussion of institutional and related work on carceral geographies, before looking at some relevant empirical examples. The separation that schooling can involve has been most starkly exposed by Sarah De Leeuw $(2007,2009)$ in a series of papers on residential schooling in British Columbia, Canada, and the forced detachment of indigenous children from their families. We ask what insights spatial ideas around incarceration, residential schooling, and institutions may have for understanding elite schools' practices. Secondly, we look at isolation in relation to the concentration of social capital and the cultivation of embodied cultural capital, drawing here on the work of Pierre Bourdieu (1986). ${ }^{3}$ As we will describe, Bourdieu frequently (implicitly) invokes the role of space and spatial practices in describing the work of elite schools. We also consider the idea that elite school spaces may function also as 'informal' educational spaces, being, as they are, rather unconventional and ostensibly alternative places of schooling that cultivate non-institutional forms of cultural capital (alongside more conventional institutional cultural capital - see Bourdieu, 1986). Here, we draw on recent work in geography on 'alternative education'. Next, and following a discussion of our research methods, the data elicited by our research project are considered in relation to different narratives of separateness produced by the schools in our sample, in contrast to the ways in which they are internationalising. The paper concludes by discussing (in light of the data) how schools are attempting actively to preserve and defend their geographical and symbolic separation, and the wider implications of this for the reproduction of social groups in contemporary society (and the crucial role schooling plays in this).

\footnotetext{
${ }^{3}$ It was Bourdieu (1996) who used the term 'The magical operations of separation' - borrowed for the title of this paper - in relation to elite educational establishments in France.
} 


\subsection{Institutional spaces and isolation}

The concept of 'institutional geographies' is clearly apposite to this discussion of school spaces, popularised in 2000 by Philo and Parr. Their definition of institutions is broad, but informative, referring to:

'those material built environments such as prisons, hospitals and asylums which seek to restrain, control, treat, 'design' and 'produce' particular and supposedly improved versions of human minds and bodies. [These usually include] Big buildings with large grounds, lots of rooms and corridors, and sizable resident populations...' (Philo and Parr, 2000, p. 513)

Interestingly, they discuss two ways in which institutions are being studied by geographers the 'geography of institutions' (i.e. where they are located) and the 'geography in institutions' (i.e. their internal arrangements). In our research, however, we attempt to link these two perspectives together, acknowledging that the spatial boundaries of the school (where schools are located in space and how their internal spaces are identified) are not straightforward to delimit (see Authors, 2014). Philo and Parr (2000) hint at this point later in their paper, when they claim that "we do not have to be discussing just one visible institution anchored in a single location, situation or site, a big blocky building with grounds and rooms, but rather can be concentrating on a spidery network of dispersed intentions, knowledges, resources and powers' (p. 514). This, we argue, is what elite English schools are practising through, amongst other things, their international activities although, as we argue here, this is not how they like to be seen. 
It is interesting to observe that geographers examining incarceration (and a recent concern with 'carceral geographies', see Moran 2009; 2012) have used the ideas of Erving Goffman (1961) extensively, particularly his notion of the 'total institution' in relation to prisons. Goffman also, however, applies this notion to describe boarding schools, leading us to consider the fruitful parallels that might be drawn between different closed institutions (such as prisons and schools). Some obvious similarities include an institutionalised and (often) single-sex environment, a degree of isolation from the outside/wider world, and the process (more or less formally) of educating. Like prisons, elite schools can be conceived as exceptional spaces, wherein distinct spatial practices are operational, with important wider social consequences. Several authors have recently drawn upon Goffman's (1961) writing to consider the role and function of spatial isolation in the prison environment. It is here that the link to carceral geographies is most apparent. As described by Moran (2013), 'carceral geography' 'was coined to describe... geographical research into practices of incarceration, viewing such carceral spaces broadly as a type of institution (Hopkins, 2010) whose distributional geographies, and geographies of internal and external social and spatial relations, could be explored' (p. 175). Carceral geography involves, amongst other things, 'critical engagement with spaces of confinement' (Moran, 2013, p. 175), and differs from earlier studies of imprisonment (which have tended to foreground the role of time and the notion of 'serving time') in the ways in which it takes seriously the significance of space. Martin and Mitchelson's (2009) definition of imprisonment and detention encompasses 'intentional practices that (i) restrict individuals' ability to move from one place to another and (ii) impose orders of space and time so that individual mobility is highly constrained, if not eliminated' (p. 460) - both elements that would seem to hold significance for understanding schooling. However, Moran (2013) has suggested that work on carceral geographies might indeed have wider significance, offering: 'a perspective on what might be 
termed 'disciplined' mobility; the geographical notion of the 'carceral' is ... useful not just for studies of incarceration per se, but also for understanding the restriction of autonomy in a much broader sense' (Moran, 2013, p. 177).

In our attempt to conceptualise the spatial isolation that is apparently such a feature of contemporary elite schooling, De Leeuw's $(2007,2009)$ work on Indian residential schools in British Columbia (BC), Canada, is also informative. Residential schools for indigenous children operated in BC between 1861 and 1984. They were, according to De Leeuw (2009) (who was commenting on a speech made by Canadian Prime Minister Stephen Harper in 2008), about: 'the removal of children from one place and their relocation to another, about school spaces regulating and curtailing behaviour, and about the emplacement of children into spaces built with the express purpose of assimilating Indigenous peoples into a colonial society' (p. 124). They had, she also argues, an 'assimilativist policy framework' (2007, p. 343). The policy of removing Indigenous children from their home communities and placing them within residential schools was finalised in response to a report published in 1879 (by Nicolas Flood Davin), which concluded that Indigenous people's assimilation would only be achieved if 'assertive educational practices predicated on boarding (residential) schools' were pursued (De Leeuw, 2007, p. 342).

Boarding served several 'civilizing' functions (De Leeuw, 2007); the role and significance of isolation in this residential environment is clear to see. The schools' imposing architecture was an important means of disorientating pupils whilst also "materially remind[ing] [them] in their every movement that their lives and culture were subordinated to a more imposing and powerful force...' (p. 345). The schools included 'an alien and disorientating gender division' which acted further to disrupt pupils' societal norms. Gender divisions were 'encoded' within schools' architecture, with pernicious consequences: 'heightened social segregation and familial breakdown which resulted from that material 
separation of genders' (2007, p. 350). Other aspects of architecture were also important: 'This layout included long straight hallways and large open areas that facilitated staff supervision and control of First Nation students and ensured the students were always within the monitoring and colonial gaze of school staffs.' (2007, p. 345).

Clearly, there are some profound differences between the experiences of pupils attending BC's residential schools in the $19^{\text {th }}$ and $20^{\text {th }}$ centuries, and those attending elite schools in England today. However, the spatial practices that these two types of school engender isolation, segregation, assimilation - are similar, and similarly seek actively to produce a particular type of 'cultured' subject (in line with dominant, external discourses pertaining to power and social hierarchy). Drawing conceptual similarities between colonial residential schools and contemporary elite public schools is perhaps an uncomfortable and not an obvious thing to do, but it is productive, in so far as it highlights the fact that schools (of all 'types') explicitly engage spatial practices (including isolation and separation) to achieve particular aims.

Some other examples, which consider the spatiality of schools as institutions, are worth briefly considering (see Collins and Coleman, 2008, for a review of 'the organization of space inside schools', p. 282). Pike and Colquhoun (2012) reflect upon how schools in the UK have deployed 'spatialised strategies', involving the policing of school boundaries 'to ensure the effectiveness of school meals policy' (p. 135). In short, schools have been 'forcing' pupils to stay on the premises during lunch times, in order to encourage the taking up of school meals. In illustrating these spatialised strategies, they describe, for example, the practice (deployed by schools) of 'locking-in': 'Eliciting comparisons with prison practices this approach involves banning children from leaving the school premises over the lunch period by locking them within the school grounds, either physically or symbolically' (Pike and Colquhoun, 2012, p. 135). The explicit reference that they make to punitive incarceration 
is unusual in the parallels that it invokes between (the spatial tactics of) schools and prisons. In another recent paper, Reh, Rabenstein and Fritzsche (2011) discuss the use of space deployed by all-day schools in Germany, where classroom boundaries are intentionally removed to promote a sense of 'open education'. The paper explores the relationship between 'space, power and pedagogical practice', and concludes that although 'open spaces' do enable some kinds of learning to prosper, new inequalities between pupils are also seen to emerge.

In this overview, we have sought to introduce some new ideas to an understanding of elite school spaces, suggesting that more recent work on institutional geographies might have something to say about the ways in which space is organised and represented within elite English schools. We will go onto to illustrate this claim, below, in relation to our empirical data. In what follows, we discuss more explicitly the functions of isolation in relation to more established literatures on cultural and social capital, and more recent work on informal and alternatives forms of education.

\subsection{Isolation, cultural and social capital, and informal education}

The extract from Harrow's website, which opened this paper, makes explicit reference to the importance of developing friendships within school - another way of describing what sociologists and economists have termed social capital (Bourdieu, 1986; Portes, 1998). Social capital (well known to proffer numerous advantages to individuals who possess it) 'takes time to accumulate' (Bourdieu, 1986, p. 241) and, as noted by Harrow School, boarding 'gives you masses of time...' to develop capital, whilst also guaranteeing that 'you are with your friends all the time'. This forced communion among pupils helps to ensure, amongst other things, the successful development of social capital. In a different (French) context, 
Pierre Bourdieu (1996) has written extensively on the practical necessity of separation for the 'production of nobility' through elite schooling:

"the process of transformation accomplished at "elite schools" [th]rough the magical operations of separation and aggregation...tends to produce a consecrated elite, that is, an elite that is not only distinct and separate, but also recognized by others and by itself as worthy of being so.' (1996, p. 102)

Here, in Bourdieu's (1996) reflections on elite schooling, we can see a nascent theorisation of spatial separation and isolation. It facilitates the social production of elites by:

'assembl[ing] adolescents with many similar social and academic properties and isolat[ing] them in a separate space. This selective confinement produces a very homogenous group whose homogeneity is further increased though the mutual socialization brought about by continued, prolonged contact...In so limiting the social area of possible associations, confinement contributes to limiting the chances of unsuitable alliances (in the broad sense). Its influence is a lasting one, moreover, for through the affective ties that bind particularly tightly during adolescence, it predetermines subsequent acts of cooptation.' (Bourdieu, 1996, p. 75)

So, not only is social capital produced though the confinement enabled by elite schooling, but (at the same time) unsuitable interactions are reduced, as is the chance of unsuitable 
relationships being forged. It is perhaps important, also, that these experiences occur at a particularly formative time in life, adolescence. Bourdieu is also keen to stress the interrelationships between social and cultural capital - the isolated school environment is related to the cultivation and accumulation of embodied cultural capital (Bourdieu, 1986; 1996) - what Bourdieu (1996) has described as a 'genuine common culture' (p. 81), which can include:

'the imponderables of manners and deportment, the typical expressions of school slang (condensed from crystallized values), the shared turns of phrase, the particular kinds of jokes, the characteristic ways of moving, speaking, laughing, and interacting with others, and especially with like-minded individuals, that create and forever sustain the immediate complicity among school mates (which goes much deeper than a simple solidarity founded on shared interests).' (p. 83)

The complexity and opaqueness of cultural capital is hinted at here: various cultural intangibles are described. This learning, although occurring within the school environment, is not formal, but largely informal, as will be discussed below. Two aspects of Bourdieu's pronouncement (linking cultural and social capital) are particularly striking, however - the notion that complicity amongst school mates is sustained forever; and that the relationships built within the elite school environment are, somehow, much deeper than normal friendships. There is, we argue here, a distinct spatiality to these social processes.

This leads on to a brief discussion of recent work in geography and beyond on informal and alternative education spaces. This is one area in which the spatial aspects of education 
(Brooks et al. 2012; Hanson Thiem, 2009; Kraftl, 2006) have been explicitly discussed (see Kraftl, 2013). We are particularly intrigued, here, in the potential relationship between informal, alternative and elite education: to what extent are elite schools 'disconnected' from 'mainstream schooling' in the manner described by Kraftl (2013) for other alternative spaces and practices of education? There is, we acknowledge, an uneasy political tension around likening elite schooling practices to alternative educational spaces, although both privilege the child in various ways. Nevertheless, drawing this parallel may indeed be productive; consequently we want to explore, briefly, two (linked) notions in relation to elite schools: a) that they function as 'informal education spaces' (Mills and Kraftl, 2014; Malcolm et al. 2003); and b) that the practice of functional isolation actively facilitates informal learning.

For some commentators, informal education is, by definition, 'beyond school' (ibid.), and so the notion that elite schools can provide suitable spaces within which informal learning can occur becomes nonsensical. Others, such as Cartwright (2012), discuss 'informal learning as a deliberate [politically charged] practice' (p. 152). To a certain extent (and space prevents a detailed discussion of this here), elite schooling in England is a 'deliberate [politically charged] practice' in so far as it seeks to do more than 'simply' educate. As statements on schools' aims and goals can attest, they attempt actively and unashamedly to create individuals who will change society. Many of the 'most influential' private schools in England produce countless politicians, and many Prime Ministers and cabinet members. Thus, one can quibble over the definition (and ethical dimensions) of informal and alternative education, but in our view elite schools $d o$ fall into these categories, even if their conception of the 'good life' might differ.

However, if we only accept the broader definition of informal education - as 'everyday and spontaneous learning experiences' (Mills and Kraftl, 2014) - it is then easy to see that elite schools might be well placed to enable such valuable 'spontaneity' to occur. 
Researchers are increasingly open to the idea that informal learning can, and does, take place within various institutional settings, including schools (Jeffs, 2007; Cartwright, 2012) and elite schools have, amongst other things, the space and time available to enable informal interactions amongst pupils and amongst pupils and staff to occur, perhaps far more than do more conventional, non-elite state schools.

What we have attempted to offer in this review of the literature is some different and unconventional ways of thinking about elite school spaces and how they might be constructed. In the next section of the paper, we discuss our research methods.

\subsection{Research Methods}

We set out in this project to examine how elite schools in England represent themselves through their websites and other publicly available materials (such as prospectuses, newsletters, blogs and twitter feeds), with a particular focus on the geography of their representations. We selected 30 schools, 10 in each of the following categories: 'private influential', 'private high-performing' and 'state selective' (there was no overlap between categories). The first category, 'private influential', was based on a recent Sutton Trust report (2012), which found that ten schools in England accounted for 12\% of all 'leading people':

'The study is based on 7637 people educated at secondary school in the UK, whose names appeared in the birthday lists of The Times, The Sunday Times, The Independent or The Independent on Sunday during 2011. These lists of names provided a snapshot of the country's leading people across a range of sectors' (p. 4). 
The second category was identified using the UK Department for Education's league table of A/AS- Level point scores (per pupil) for 2012. Finally, our last category (high performing, selective state schools) was also created using the A/AS- level league table. We decided to sample in this way so as to consider any differences that might become apparent between elite school 'types'. We also wanted a substantive sample from each category (ten from each was deemed satisfactory). Clearly, such a relatively small sample cannot aim to be representative of all elite schools in England, but we had more modest aims - to uncover the 'hidden' geographies within the public face of leading elite schools in England with sufficient qualitative sensitivity and depth. Of the 30 schools examined in total, 20 were private (feepaying), 14 were boarding and 10 had fees of $£ 10 \mathrm{~K}$ per term (or more). At sixth form, 10 were girls only, 7 were boys only and 13 were co-educational. We should note that we deliberately included in our analysis non-boarding, as well as boarding schools, and found that their representations did not differ significantly with regards to their public face. In the discussion of our data that follows, we identify schools by type and a randomly assigned number (e.g. Private Influential \#1, High-Performing State \#3, and so on).

Wilkins (2011) has considered the role that visual representations found in school promotional materials play in 'school choice' - 'how schools work to define themselves, culturally, pedagogically and historically, in a visually mediated field of choice, and how this symbolic and material work is achieved through the visual arrangement of particular referents.' (p. 70). Indeed, work on visual methodologies (Rose, 2012) has significantly informed how we approached this research. For our analysis, we utilised a pre-designed table, which we then populated with information on each school, including: dominant visual images on homepages; references and imagery drawn upon by the head teacher in their 'statement/message'; representations of university admissions; and so on. In addition to the web-pages themselves, we also downloaded and examined available prospectuses and 
newsletters, as well as blogs and twitter-feeds. It was important to us that this information was publicly available, as this gives an insight into how the school wants to be seen (and sees itself) by the outside world. In the next section of the paper, we present an analysis of our findings.

A note is needed, here, on the ethical implications of using websites as a source of primary data. Concerns could be raised, we freely admit, in relation to our use (without explicit permission) of publicly available materials on schools' websites. As Young (2013) writes on this very issue: 'At this time there is not agreement in the research community around classification of certain online data as either text-based or human-subject research and exactly which contexts render content as public or private. This in turn raises questions about obtaining consent, third-party data and publication of visual data' (pp. 284-285). In relation to our research project, we would argue that not gaining consent to use publicly available information displayed on schools' websites is acceptable, because this information was deliberately created for public consumption. This is different from other web-based postings, where information may be de facto 'public', but was not created for public display. We also, in addition, strive to maintain the anonymity of the schools represented in our data, so that individual schools are not immediately identifiable.

\subsection{Narratives of separateness}

In this section, we draw directly from our empirical data to describe the extent of separation depicted by elite schools in England. As a general observation, what struck us most among the combination of words and images used by these schools was a sense of inwardness, achieved through a highly controlled interaction with the outside world. Pupils are, in some cases quite literally, 'shut off'. Sometimes, and this isparticularly notable for 
girls' schools, this would seem to relate to a need to depict physical and emotional safety and protection to parents. More usually, isolation was linked to 'cultivation' - separateness enables the inculcation of particular traits required in the cultivation of valuable cultural capital through formal and informal learning (Bourdieu, 1986). In what follows, we discuss the most prominent of these images to have emerged from our analysis. We begin with a discussion of home pages, as these have (in most cases) been carefully crafted to project a very particular, striking and immediate image of the school.

\subsection{Home pages}

The home pages of elite schools' websites give us an initial but significant impression of how the school seeks to present itself to the outside world. Schools' home pages usually featured a set of dominant rolling images. In boys' schools, images of sport are rife - in nearly every case a cricket match is depicted, with the school grounds as a back drop. Common images include: pupils wearing school uniform and engaged in some 'learning' activity; and (at least one) picture of the school's (old) architecture and grounds. Architecture includes religious images of chapel interiors. ${ }^{4}$ These are, by all accounts, very traditional depictions of an archetypal 'elite English school'. None of the schools deviated, in any significant way, from this limited narrative. Notably, the pupils shown are overwhelmingly ethically/racially homogenous (there are very few 'non-white' faces on homepages ). Neither is the ethnic diversity that the schools, in reality, contain (given oftensubstantial numbers of overseas pupils) reflected in schools' on-line portrayals more generally.

\footnotetext{
${ }^{4}$ The religious metaphors that Bourdieu often evokes in his discussions of elite schooling are meaningful for the schools themselves, which frequently draw on religiosity as an explanation of and justification for their practices (religious images are heavily represented in their websites).
} 
Most school home pages include a link to a 'headmaster's/headteacher's statement', two examples of extracts from these are given below:

It would be hard to imagine school life in a more beautiful place than XXX. With a setting where the College melds the town with the countryside, it offers broad all-round opportunity. School days should be fun, a mixture of intellectual endeavour and a wide co-curricular programme.

XXX's blend of tradition and progression is all about true boarding. Life here is exciting with an insistence upon high academic performance underpinned by artistic and sporting programmes at the highest levels.

The 24/7 nature of the residential programme is the basis to this. XXX, once joined, is not so much a school, but more a way of life (Private Influential \#5)

$* * * * * * * * *$

Through the X centuries XXX has been educating boys much has changed, but the essence of school life has remained as described in the mid-nineteenth century by XXX.

He wrote that at a great school it is not just knowledge that is acquired, nor even the 'shadow of lost knowledge' that later protects you from many illusions, but most importantly the 'arts and habits' that last for a lifetime. (Private Influential \#3).

These statements speak to more than just formal learning and certification. The acquisition of credentials is not even mentioned. Rather, they invoke the embodied cultural capital described by Bourdieu (1986) through reference to schooling as a 'way of life' that instills 'arts and habits' that 'last a lifetime'.

We spent some time examining the content of all these statements for each school, as they were clearly important (prominently featured on websites) and represented the 'ethos' of these institutions. Common words used in these statements include: 'historic', 'history', 'tradition', 'Christian', 'community', 'legacy', 'service' and 'pioneering.' Aspects of the 
international were rarely mentioned. Interestingly, when terms such as 'pioneering' or 'innovative' are used, it is always in conjunction with 'tradition'; any sense of newness is tempered by a commitment to the old. Religiosity features strongly in many schools' narratives, stressing Christian values and/or spirituality and faith as fundamental aspects of everyday life.

\subsection{Depictions of architecture and isolation}

Architecture - and the physical space of the school - is dominant in the imagery used on web pages, and plays a part in representations of isolation. Safety and comfort found in reference to the past is evoked through the architecture. After photographs of pupils, the next most common image populating websites was that of school buildings, whether close-up shots of aspects of architecture or long-range shots of buildings within school grounds. Indeed, it is necessary to speculate on just what such consistent and repetitive images of the external facade of buildings tell us about the message these schools are trying to relay. As most (although not all) of the buildings shown are appreciably old (hundreds of years in many cases and reminiscent of some Oxbridge colleges in style), these images clearly support a narrative stressing tradition, stability and reliability. In his analysis of how two schools in England represent themselves on their websites, Wilkins (2011) describes 'the architectural magnificence conveyed through 'old' buildings to communicate a sense of structure, history and grandeur, in particular, a desire for a past order of social relationships' (pp. $79-80$ ). He continues: 'the use of 'old' buildings conveys a strong impression of a past order of social relationships based on a way of life that is felt to be more predictable, stable and protected...' (p. 80). His observations are clearly apposite, too, for our analysis of elite schools' representations of architecture on their websites. 
The similarity of many buildings in style and age to common representations of Oxbridge colleges must surely work, on some level, to support schools' claims that they are very successful in getting their pupils into top UK universities. In fact, what is striking about the websites of elite schools is the overwhelming emphasis they place on securing admission to Oxford or Cambridge universities.All other universities, either in the UK or abroad, are deemed second best or suboptimal (see Authors, 2014). This is despite the fact that - as noted earlier and will be discussed later - for some schools, significant numbers of sixth-form students (up to $15 \%$ of the cohort) are applying to and accepting places at North American institutions. Although mentioned within their webpages, this fact is generally downplayed. One implication, of course, is that schools are preparing young people for an Oxbridge higher education through the continuity of a 'familiar culture', materialised in the buildings/architecture.

\section{3 'Disciplined mobility'}

'Boarding schools offer a wealth of opportunity for boys to try new things and take risks within the protection of a close and supportive community' (Private Influential, \#3).

The notion of 'disciplined mobility' (Moran, 2013, p. 177), taken from work in carceral geographies, helps us to understand the kinds of (highly circumscribed) interactions pupils in elite schools appear to have with the outside world. As the quotation lifted from the website of one school suggests, schools need to balance a desirable kind of risk against a sense of 'protection' and keeping the boys close. In what follows, we will consider the ways in which elite schools frequently practice 'disciplined mobility' and the role that formal expeditions 
play in this. This could be considered as internationalisation 'lite' - a highly sanitised and circumscribed engagement with 'the other'.

It is interesting and informative to compare two examples (in many ways representative of their respective school types) - one from the 'private influential' category (a boys' boarding school) and the other from the 'high performing private' category (a girls', day only school). The differences, in terms of how they represent overseas trips and exhibitions, are quite striking. Private Influential (\#3) school has only half a page of text on its various expeditions (to Malawi, Kenya, Nepal, Tibet, Greece and Rome) and sports teams' trips (to Australia, New Zealand, Hong Kong, East Africa and the USA), and no trip-specific photographs (just two generic images of pupils engaged in 'learning' activities). The text reads as follows:

'Expeditions are made both during the half and in the holidays:

- Field-trips are undertaken as part of some academic courses.

- Boys studying modern languages can take part in exchanges with schools in France, Germany, Spain, and Russia.

- The choir gives concerts both at home and abroad.

- School teams have travelled in recent years to Australia, New Zealand, Hong Kong, East Africa, and the United States, among other places.

- The Mountaineering Club runs expeditions to mountain and moorland areas, which offer boys the opportunity to acquire basic skills in camping, walking, and climbing, and later to learn more advanced techniques. 
Societies and individual masters also organize expeditions to places and events of interest, both at home and abroad. There have been numerous trips to Greece and Rome, and major expeditions to Malawi, Kenya, Nepal, and Tibet.' (Private Influential \# 3)

As is perhaps clear from this text, some very significant and exciting international trips $d o$ occur, but they are notably downplayed on the school's website. It is our contention that they go against the prevailing narrative stressing insularity, protection and communion.

In contrast, the High Performing Private school (\#2) has a dense page of text on its various international activities (see below) as well as links to impressive and very detailed accounts of three recent trips (which contain vast numbers of photographs, apparently taken by pupils themselves). The web-page on 'trips' reads:

'Trips give our pupils unique opportunities to develop their resourcefulness and initiative and to spend time together in a less formal environment. Each trip is different. Some are directly related to the curriculum, some are designed to promote social awareness, or to enhance physical skills, self-reliance and team-working. Others will extend their knowledge of the world. The common factor is that they all make an essential contribution to your daughter's development and education in the broadest sense of the word. Our duty of care on educational trips and visits is the same as that provided during the school day. Detailed arrangements are sent to parents and vary depending on the circumstances of a particular trip.' 
They go on to discuss various day-trips, before returning to exemplify the range of national and international expeditions engaged in, including: 'residential trips from the Thirds (Year 7) upwards... U4 [engage in a] World Challenge trip to Croatia.... Some pupils from the U4 (Year 9) and above also take part in language and cultural exchanges. ... Girls in the L5 (Year 10) and above are offered World Challenge and similar trips (including Bolivia, Ecuador, Kenya and Tanzania, Madagascar and Mongolia)... Sports Tours (including Barbados and New Zealand and Fiji) and subject linked trips (including to, Iceland, Egypt, Poland, Madrid, New York, Lyon and Paris). We also offer ski trips for beginners every other year.' (High Performing Private \# 2).

In general, the 'less influential' elite private schools are far more keen than their 'Private Influential' counterparts to exhibit internationalisation, and would seem to value cosmopolitanism far more highly. Thus, we conclude that a reluctance to embrace internationalisation as part of their public face is very much confined to the most privileged and exclusive schools in England.

It is worth mentioning, also, the emphasis placed by nearly all schools upon the Duke of Edinburgh's (D of E) Awards and the opportunities given to pupils to achieve these awards (at bronze, silver and gold level) beyond the school grounds. D of E offers the chance for controlled adventure. One school has a related programme of 'adventurous' outdoor education, as described in the following quotation: 'There are two principal aims of XXX's programme of Outdoor Education: first, to develop in XXXs qualities of self-reliance, teamwork and leadership; and second to equip them with the skills to enable them to enjoy the world's open spaces with confidence and in safety'. '[H]ighlights involve extended periods far from the school'... and pupils undertake 'adventurous training in wild country 
such as Snowdonia and Dartmoor' (Private Influential \#1). The mention of 'far from the school' serves to underscore the fact that, on a day-to-day basis, schools are very much concerned with keeping pupils close.

\subsection{Actual internationalisation}

The preceding commentary on how schools are depicting their isolation (through images and texts) needs to read alongside the actual extent of their international involvements. A recent article in The Telegraph newspaper (September 2014) reported on discussions at the Headmasters' and Headmistresses' Conference, which represented 260 UK independent schools, including those found within our sample. One issue raised at the conference concerned the rise in tuition fees (300 percent since 1990), significantly above rises in wages over the same period. One head teacher claimed that these were necessary in order to attract the best teaching staff because schools are 'competing internationally' for parents and attempting to provide a 'world-class' education. These schools, it was claimed at the conference, are 'internationalising' at a very steady rate.

The internationalisation that we observed emerged from a detailed reading of schools' webpages and prospectuses, as noted above. Our project identified 4 dominant types of international engagement by the most privileged of elite English schools: i) the overseas destinations of sixth formers for higher education (HE); ii) the presence of international pupils; iii) the teaching of international curricula; iv) and the growth of satellite schools overseas (particularly in the middle east and east Asia). Although we have discussed these in depth in an earlier paper (Authors 2014), it is necessary to make some reference to them here in order to illustrate just how incongruous the aforementioned depictions of isolation are. 
It was common for schools (particularly in the private sector) to provide some data on their websites pertaining to the HE destinations of their sixth-formers on leaving the school. What we found was that a surprising number of pupils have secured places at overseas universities over the past few years - anything from a handful (four or five) to 29 in the case of one particular school (Private Influential \#3). It was also notable that schools provided much administrative support for pupils wanting to apply to universities outside of the UK, whether in the form of a 'special advisor' (Private High Performing \#10), or facilitating visits from Ivy League institutions seeking to recruit pupils (Private Influential \#10). One school (Private High-Performing \#4) runs a HE fair especially for North American universities. However, that said, in relation to their websites as a whole, this information is rather buried and not easily or quickly accessible. Instead, entry to the UK's top universities (notably Oxbridge and, to a lesser extent, Russell Group institutions) remains at the forefront of schools' attempts to market themselves to the outside world.

We were also able to access data from schools' websites and public documents available from the Independent Schools Inspectorate on the number of international pupils attending many of the schools in our sample. Space prohibits a detailed breakdown of these figures here. However, to give some indication of this: 20 percent of pupils attending Private High performing \#7 and Private Influential \#10 and 17 percent at Private High-Performing \#10 were classed as 'international'. Other schools had lower although still significant percentages of international pupils. And yet, as noted, they were rarely represented prominently (let alone celebrated) on schools' webpages.

We also noted that over a quarter of schools in our sample offered the International Baccalaureate (IB) to sixth-form pupils, reflecting broader internationalisation of schools' curricula. And, as noted above, more and more private schools are opening satellite campuses 
abroad ( 5 of the schools in our sample). This is an extremely significant development in the internationalising activities of elite English schools, and yet largely hidden from public view.

\subsection{Theorising functional isolation}

In this final section, we want to reflect upon what our findings have to say about elite schools' spatial practices in relation to functional isolation. In the context of elite schools, pupils' isolation enables two important objectives to be met: i) the creation of a distinct subject-persona unique to the school (i.e. embodied cultural capital); ii) the concentration and cultivation of social capital. Both are facilitated by opportunities for informal learning. There is an important international and historical context to this, which may make the situation in English/British elite schools somewhat distinctive. Historically (related to colonialism) and today, an 'English' education is still deemed valuable in a global educational market place. High worth continues to be attached to the English language (spoken with an English accent) and English cultural traits - something not lost on the marketers of British education overseas, including the British Council. Consequently, there is a virtue (and financial benefit?)to be had from maintaining a high degree of Englishness within the confines of the most elite English schools. Somewhat ironically, we argue, these objectives are in part related to the desire to attract international pupils (The Telegraph, 2014), where non-UK parents are known to be keen to avoid schools with a high concentration of international/immigrant students (Authors, 2014).

\subsection{Creating the (English) subject}


'They [elites] may also be socially instituted and guaranteed by the application of a common name [e.g. a family or of a school]...' (Bourdieu, 1986; p. 249).

Elite schools - but especially those in the Private Influential category (the most expensive, most exclusive institutions) - are centrally concerned with creating a 'type' of person; a person who embodies the school's core values and will carry this identity with them through their lives (or, as Bourdieu describes, 'forever'). For many schools, these identities are named (to enable easy mutual-recognition and to underscore elite club membership) - for example: a) Charterhouse School: ‘Carthusian’; b) Eton College: ‘Etonian’; c) Harrow School: 'Harrovian'; d) Marlborough College: 'Marlburian'; e) St Paul's School: 'Pauline'; f) Wellington College: 'Wellingtonian'; and g) Winchester College: 'Old Wykehamist'. To an outsider, these names appear strange, anachronistic and, above all, alienating. Reference to the school persona can be found throughout the websites of the most influential private schools. This serves a number of functions. First, it enhances the metaphorical separation of pupils from non-pupils - only alumni of this particular school can call themselves by that name. It is, in all senses, a badge to be worn (mentioned in conversation, added to one's CV, used to gain entry to various exclusive clubs after the pupil has long left the physical grounds of the school). It is inextricably linked to the creation of both social capital and cultural capital (see discussion below). Second, it provides (in a crude sense) a branding mechanism for the school, facilitating marketing. Third, the names reference tradition - most have been around for hundreds of years, and suggest ineffable links between pupils of this generation and those who have passed through the school before them. These goals are achieved in part through the 24/7 aspects of many elite schools, where (like other forms of alternative education), the creation of a 'rounded person' is inseparable from more substantive and formal educational goals. 


\subsection{Concentration of social capital and the cultivation of cultural capital}

As suggested above, isolation within the school grounds directly facilitates the creation of social capital amongst pupils. Bourdieu (1986, 248 - 249) defines social capital as: 'resources ... linked to the possession of a durable network of ... institutionalized relationships of mutual acquaintance and recognition.' Intense face-to-face interaction, over time, is a crucial element of social capital (and its creation), and thus, the elite school environment provides the perfect setting for, and container within which, this can occur (as too, perhaps, does the prison).

Social capital also delivers tangible rewards; and the role that social capital plays in 'status attainment' has been widely documented in the literature (Coleman 1988; Lin 2001). Status attainment can include academic achievement (Coleman 1988) or favourable employment outcomes (Portes 1995).

The concept of 'institutional social capital' (Brinton, 2000) is particularly apposite to our discussion. Brinton (2000, pp. 289 - 290) succinctly describes the value of institutional social capital to young people engaged in job-seeking: 'If institutions (such as schools) have a stock of social capital to which youth have access, this arguably multiplies the opportunities young people would otherwise have had through information or introductions provided by their own family, friends, and acquaintances.' Social capital acquired within a formal institutional setting, she argues, can act as a direct link to employers and, consequently, may enhance employment opportunities. This is particularly true for elites, as a number of studies have shown (Hall 2011; Lee and Brinton 1996; Waters, 2007). 


\subsection{Conclusions}

It is an undeniable fact that a small number of elite English schools contribute a vast amount in terms of leadership and the exercise of power in the arts, politics and the economy within contemporary British life. As already observed, the Sutton Trust's report was keen to stress that only 10 schools in England could account for $12 \%$ of all 'leading people' in the UK. A recent article in The Independent newspaper (August 2014) has also noted that '71 percent of senior judges, 62 percent of senior armed forces officers, 55 percent of Whitehall permanent secretaries, 50 percent of House of Lords members and 43 percent of newspaper columnists were privately educated.... One in seven judges went to five independent schools - Eton, Westminster, Radley, Charterhouse or St Paul's Boys' (Grice, 2014). However, methodological difficulties (Beaverstock et al., 2004; Beaverstock, 2005), as well as a lack of moral justification, have often meant that elite practices fly below the radar of academic study, escaping scrutiny. From the outset, this paper offers a modest corrective to this situation, with broader implications for understanding the ways in which societies function and inequalities are reproduced through education.

In the study reported here, we sought to provide a qualitative assessment of how elite schools in England are representing themselves to the outside world (their 'public face'), through their websites and other publicly available materials (prospectuses, newsletters, blogs and twitter feeds). We examined 30 schools, under the categories of 'private influential', 'private high-performing' and 'high performing state selective'. Our analysis strived in particular to uncover the geographical nature of visual and textual representations within elite school websites. We were struck by the strong 'isolationism' narrative that characterised these materials, particular in light of their actual and significant internationalisation (see Authors, 2014). It is worth noting again, however, that our analysis is based on online visual and textual representations - different perspectives might emerge if we had gone into the 
schools and talked to staff and pupils. Nevertheless, it is our contention that these representations, propagated by elite schools (and regularly reviewed for content and format) are important - they all clearly spend a great deal of time and money maintaining their webpresence, with particular effects in mind (not least, to attract prospective parents and pupils). If they are presenting themselves as insular and separate despite clear evidence of internationalisation, it is meaningful to consider why this might be the case.

In an effort to theorise this functional isolation, the paper drew from work on institutional and carceral geographies. 'Disciplined mobility' proved to be a useful concept, neatly capturing the nature and extent of external interactions pursued by elite schools. Mobility in these environments is tightly controlled and limited in scope. Goffman's notion of the 'total institution' was also helpful, as it could be seen to characterise the aims of (if not the actual outcomes for) many elite schools. The paper contributes towards an expansion of the geographical notion of 'carceral', as called for by Moran (2013), in the way in which it considers broader meanings of the restriction of autonomy and the function of confinement/isolation. Utilising a very different set of literatures, we also drew upon work on 'informal learning' and 'alternative education' (e.g. Kraftl, 2013). In an intentionally provocative move, the paper has deliberately brought together ideas that make uneasy bedfellows; for example, we made the point that elite school spaces are suggestive in many ways of other alternative educational spaces and could be conceived to be equally political in their intentions (albeit with different conceptions of the 'good life'). We feel that this unusual way of looking at elite schooling has been productive and contributes, also, to the extant literature on alternative and informal schooling.

The paper observed some ways in which schools portrayed isolation online (on home pages, through headteachers' statements, through depictions of architecture, and through controlled engagements with the outside world) and used these theoretical tools to consider 
the functions of their spatial practices, namely, the creation of a subject-persona and the concentration of social capital, both of which are achieved through informal learning. There is an important underlying international context to the imperative to create the elite English subject - Englishness in education continues to be valorised globally, just as elite English schools are actively attempting to court (the fees of) a wealthy and privileged international elite (Paton, 2014).

As suggested, our project on the spatial practices of elite English schools has some implications for understanding broader social inequalities. The very act of researching elite institutions - forcing them into the spotlight - is a political gesture. Openly challenging the taken-for-granted spatial isolation of elite English schooling, by throwing it into stark relief against significant but largely concealed international and internationalising agendas, has also been productive. Far more research on the spatial practices of elite schools is needed, however - to date, their geographies remain significantly hidden, despite their national and increasingly international importance. There is an emergent literature on the spatial practices of some alternative learning spaces (see Kraftl, 2012), including schools, but this has not yet included elite school spaces. We have argued here that perceiving elite schooling as 'alternative' can be useful, and this might constitute one such future research agenda. Another, related project would be to understand the elite school in far more depth - an ethnographic account of the 'most influential' schools' spatial practices would be extremely valuable, if difficult to achieve in practice. Finally, we are particularly interested in uncovering further the spatial reach of elite English schools - both locally and increasingly internationally. 


\section{References}

Aguiar, A. and M. Nogueira. 2012. Internationalisation strategies of Brazilian private schools. International Studies in Sociology of Education. 22 (4), 353 - 68.

Authors. 2014.

Authors. 2011.

Beaverstock, J. V, Hubbard, P. and Short, J. 2004. Getting away with it? Exposing the geographies of the global super-rich Geoforum. 35(4), 401-407.

Bourdieu, P. 1986. The forms of capital. In Handbook of Theory and Research for the Sociology of Education. J. G. Richardson (ed.). NY: Greenwood Press, 241 - 258.

Bourdieu, P. 1996. The State Nobility: Elite Schools in the Field of Power. Stanford, California: Stanford University Press.

Brinton, Mary. 2000. Social Capital in the Japanese Youth Labor Market: Labor Market Policy, Schools, and Norms. Policy Sciences 33(4).

Brooks, R. Fuller, A. and J. Waters (Ed.) 2012. Changing spaces of Education: new perspectives on the nature of learning. London: Routledge.

Brown, P. 1995. Cultural Capital and Social Exclusion: Some Observations on Recent Trends in Education, Employment and the Labour Market, Work, Employment and Society, 9 (1), 123.

Campbell-Price, M. and T. Duncan .2014. Experiencing the (different) everyday on an international school-led trip: a New Zealand exemple. Presentation to the RGS-IBG Annual Conference, 26 - 29 August 2014, London. 
Coleman, J. 1988. Social capital in the creation of human capital. American Journal of Sociology 94: S95 - S120.

Collins, D. and Coleman, T. 2008. Social geographies of education: looking within and beyond, school boundaries. Geography Compass 2(1), $281-299$.

De Leeuw, S. 2007. Intimate Colonialisms: The Material and Experienced Places of British Columbia's Residential Schools. The Canadian Geographer. 51 (3), 339 - 359.

De Leeuw, S. 2009. If Anything is to be Done with the Indian, We Must Catch Him Very Young: Colonial Constructions of Aboriginal Children and the Geographies of Indian Residential Schooling in British Columbia, Canada. Children's Geographies. 7(2), 123-140.

Grice, A. 2014. Old boys' club still dominates public life, according to major new report. The Independent, 28 August 2014.

Goffman, E. 1961. Asylums: Essays on the Social Situation of Mental Patients and Other Inmates. Berkeley: Penguin Books.

Hanson Thiem, C. 2009. Thinking through education: the geographies of contemporary educational restructuring. Progress in Human Geography 33 (2), 154 - 173.

Jeffs, T. 2007, Crossing the divide: school-bases youth work, in Harrison, R., Benjamin, C., Curran, S. and Hunter, R. (eds.) Leading Work with Young People. Milton Keynes: OUP, pp. $97-108$.

Kraftl , P. 2006, Building an idea: the material construction of an ideal childhood. Transactions of the Institute of British Geographers 31, 488 - 504.

Kraftl, P. 2013. Towards geographies of 'alternative' education: a case study of UK home schooling families. Transactions of the Institute of British Geographers, 38: 436-450 
Kraftl, P. 2013. Geographies of Alternative Education: Diverse learning spaces for children and young people. Bristol: Policy Press.

Lee, S. and Brinton, M. 1996. Elite education and social capital: the case of South Korea. Sociology of Education 69 (3), 177 - 192.

Malcolm, J., Hodkinson, P. and Colley, H. 2003. The interrelationships between informal and formal learning. Journal of Workplace Learning 15 (7/8), 313 - 318.

Martin, L. and Mitchelson, M. 2009. Geographies of detention and imprisonment: interrogating spatial practices of confinrment, discipline, law, and state power. Geography Compass $3(1), 459-477$.

Massey, D. and Denton, N. 1993. American Apartheid: Segregation and the Making of the Underclass Cambridge: Harvard University Press

Mills, S. and Kraftl, P. (2014) (eds) Informal Education, Childhood and Youth: Geographies, Histories, Practices. Basingstoke: Palgrave Macmillan

Mitchell, K. (2003), Educating the national citizen in neoliberal times: from the multicultural self to the strategic cosmopolitan. Transactions of the Institute of British Geographers, 28: $387-403$

Moran, D. 2013. Carceral geography and the spatialities of prison visiting : visitation, recidivism, and hyperincarceration. Environment and Planning D : Society and Space 31, 174 $-190$.

Moran, D. Pallot, J. and Piacentini, L. 2009. Lipstick, lace, and longing : constructions of femininity inside a Russian prison. Environment and Planning D@ Society and Space 27, $700-720$. 
Moran, D., Piacentini, L. a nd Pallot, J. 2012. Disciplined mobility and carceral geography : prisoner transport in Russia. Transnations of the Institute of British Geographers. 37, 446 460.

Moran, D., Piacentini, L. and Pallot, J. 2012. Disciplined mobility and carceral geography: prisoner transport in Russia. Transactions of the Institute of British Geographers, 37: 446460

Ong, A. 1999. Flexible Citizenship; the Cultural Logics of Transnationality. Durham and London: Duke University Press.

Paton, G. 2014. Private school fee rises 'driven by increase in wealthy foreign pupils. The Telegraph, 29 September 2014.

Portes, A. (1998) Social capital: its origins and applications in modern sociology. Annual Review of Sociology 24, $1-14$.

Reh, S. Rabenstein, K. and Fritzsche, F. 2011. Learning spaces without boundaries?

Territories, power and how schools regulate learning. Social and Cultural Geography 12 (1), $83-98$.

Rose, G. 2012. Visual Methodologies: An Introduction to Researching with Visual Materials ( $3^{\text {rd }}$ Ed.) California: Sage.

The Sutton Trust (2012): http://www.suttontrust.com/public/documents/1leading-peoplereport-6-.pdf

Waters, J. L. 2007 "Roundabout routes and sanctuary schools": the role of situated educational practices and habitus in the creation of transnational professionals. Global Networks 7 (4), 477 - 497. 
Wilkins, A. 2011. School choice and the commodification of education: a visual approach to school brochures and websites. Critical Social Policy 32 (1), 69 - 86.

Young, K. (2013). Researching young people's on-line spaces, in te Riele, K. and Brooks, R. (eds) (2013) Negotiating Ethical Challenges in Youth Research, New York, Routledge (pp. 284 - 309). 